University of the Witwatersrand, Johannesburg-Institute for the Study of Man in Africa

A commitree was recently set up, under the Chairmanship of Professor Philip Tobias, to establish an Institute for the Study of Man in Africa, in commemoration of Professor Raymond A. Dart, the South African physical and palaeo-anthropologist, who retired from the Chair of Anatomy in the University of the Witwatersrand at the end of 1958.

The primary aims of the Institute will be to advance the study of the living peoples of Africa, and to foster the study of Man's ancestry in Africa. Special attention will be given to medical, social, cultural, and physical anthropology, palaeontology, archacology and demography. The Institute will have as its four main bases: research, in the field and in the laboratory; education and training of field workers; conservation of many forms of Africana in a museum; and co-operation with other universities and research Institutes with similar aims.

An appeal was launched in 1958 in the hope of raising an initial sum of $f_{10,000,}$ which is regarded as the minimum amount on the basis of which approaches to research foundations and trust funds may be made for major financial assistance. Contributions will be welcome; cheques and postal orders should be made payable to the Raymond Dart Institute Fund, and sent to the Medical Graduates Association, r4a Kotze Street, Hillbrow, Johannesburg.

\title{
Award of the Prix Bruel for M. Alexandre's Ethnographic Survey of the Pahouin
}

Ir has been announced that the Prix Bruel of the Académie des Sciences d'Outre-Mer has been awarded to M. Pierre Alexandre, for his book Le Groupe dit Pahouin (Fang-BoulouBeti), written in collaboration with M. Jacques Binet. This is one of the sections of the Ethnographic Survey of the International African Institute; it is published by the Presses Universitaires in France at 1000 frs. and may be obtained from the Institute, price $17 s$.

\section{East African Institute of Social Research Conference, June 1958}

THE following papers were presented and discussed at the East African Institute of Social Research's summer conference: Some aspects of Nyamwezi witch belief, by R. G. Abrahams; An experimental classification of political systems, by C. H. W. Howe; Family Waqf in Zanzibar, by P. A. Lienhardt; Piercing, by M. J. Ruel; A preliminary field report of land tenure in West Ankole District, by D. J. Stenning; Some economic aspects of Kumam marriage and family, by $\mathrm{J}$. van Velsen; A preliminary report on tribal differentiation and social groupings on the southern Kenya coast, by G. Wijeyewardene; The Hadza: first impressions, by J. C. Woodburn.

\section{Inter-African Conference on Industrial, Commercial, and Agricultural Education, Luanda, 1957}

THE report has now been published of the above conference which was held at Luanda under the auspices of C.C.T.A./C.S.A. and attended by delegates from Belgium, the Federation of Rhodesia and Nyasaland, France, Ghana, Liberia, Portugal, the United Kingdom (including Kenya, Nigeria, Tanganyika, and Uganda), and the Union of South Africa. Among the conclusions reached by the Steering Committee was the recognition of the common ground, especially in the field of vocational training, between educational and labour specialists, and the desirability of reciprocal attendance by such specialists at InterAfrican conferences in these fields. The report contains detailed accounts of the work and recommendations of the various Committees, as well as a synthesis of reports on Vocational Guidance which is recognized as having an important part to play in future in the develop- 